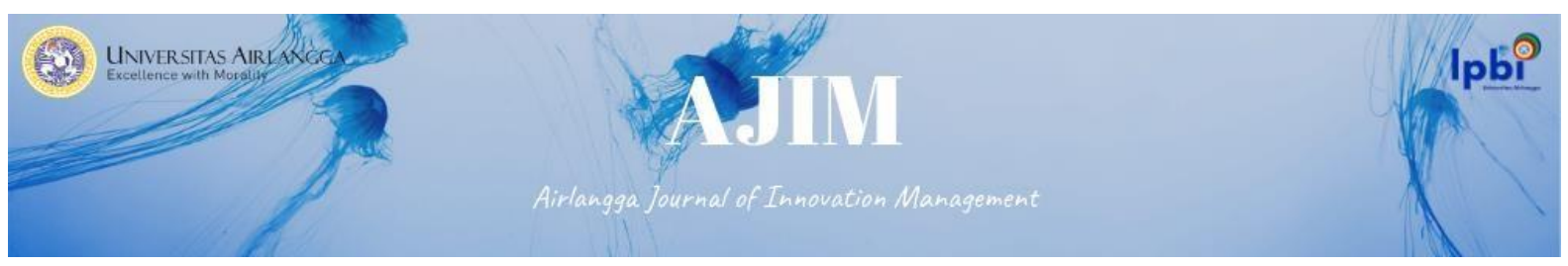

Vol. 2 No.2 Oktober 2021

e-ISSN: 2722-5062

DOI : 10.20473/ajim.v\%vi\%i.25998

\title{
THE INFLUENCE OF COMPENSATION TO EMPLOYEE PERFORMANCE IN FOOD SECURITY AND ANIMAL HUSBANDRY OFFICE
}

\author{
Muammar K. Harahap ${ }^{a^{*}}$, Azhadi Halomoan ${ }^{\mathrm{b}}$, Raja Pandi Siregar ${ }^{\mathrm{c}}$, Ramlah Sritilawah Siregar \\ a,b,c,d Magister Program, Faculty of Economics, Universitas Islam Sumatera Utara \\ *Corresponding e-mail : muammarkadapihrp@gmail.com
}

\begin{abstract}
Compensation is considered very important tool to increase employee morale in the progress of organization or bureaucracy in a company or institution. By giving any compensation, every employee will have high morale at work. So that the company can achieve the targets that have been set, even more than it should be. Likewise with this study which will look at the effect of compensation on improving employees performance the food security and animal husbandry office in North Sumatra province. Compensation functions as a form of reward received by employees in relation to rewards or for their work performance, both regularly and situational in a company. This research aims to see an effect of compensation in food security and animal husbandry North Sumatra. The process of collecting data in this study uses quantitative methods that are collected based on population and samples at research location. The researcher in this case has determined sample in data collection in accordance with specified problem. As for the population in this study, amounting to 53 people who work in the office for food security and animal husbandry. From the questionnaire given to 53 respondents, each respondent answered 10 questions that had been prepared beforehand. As for this research, it is found that the partial compensation variable has a significant effect on employees performance at Food Security and Animal Husbandry Office of North Sumatra Province. So it can be concluded that compensation is very influential in increasing morale of employee performance and it will have a good impact on activity of food security and animal husbandry in North Sumatra.
\end{abstract}

\section{Keywords: Influence, Compensation, Employee Performance, Food Security Service}

\section{Introduction}

Based on Lateiner (1995), Moekijat (1996), Soeprihanto (1996), Human Resource Management is all activities carried out starting from activities planning, organizing, directing, coordinating, to controlling all values which is the power of man, for used for the benefit of human life (Nitisemito: 1998 and Saydam 2000). Human resource management is matters related to development, utility, and protection of human resources (Simamora, 2003). This is because the success or failure of an organization depends on and is influenced by human resources as executing workers, therefore the employment humanizing program is a fundamental final progress in efforts to improve human condition in work. Sedarmayanti (2009) emphasizes that human resource management is policy and practice of 


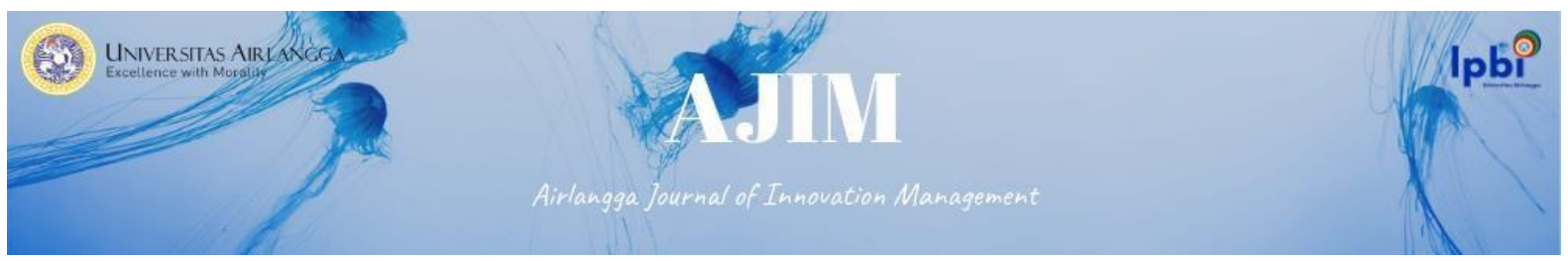

determining human resource aspects of a management position, including recruiting, screening, training, rewarding and appraising.

As phenomenon that occurs related to compensation at the Food and Animal Husbandry Service of North Sumatra Province, that the good compensation applied in organization / company has not been fulfilled (Staff Staff, 2020). According to Mangkunegara (2008) compensation refers to all forms of payment or gifts for employees and comes from their work. So that compensation becomes a form of reward received by employees in relation to rewards or remuneration for their good work performance which is given regularly.

So it proves that compensation variable has a significant effect on employee performance. Compensation provided by the organization to employees can improve employee performance so that company / organizational goals can be realized (Adhi, 2017; Hidayah, 2016). The objective to be achieved in this study is to analyze an effect of compensation on employe performances at Food Security and Animal Husbandry Service of North Sumatra Province.

Compensation is considered to have an important role in improving the performance of employees at North Sumatra Food Security and Animal Husbandry Service. Because effect of compensation is often considered by managers to be one of driving factors in improving employee performance in organization. Therefore, government at North Sumatra Food and Animal Security Service must have a serious plan in providing additional compensation for each employee. This analysis is basis for researchers interested in revealing how much influence compensation has had on improving employee performance in Food and Animal Husbandry Department of North Sumatra Province.

\section{Literature Review}

\section{Compensation}

According to Aritonang (2005: 34) compensation is all income in form of money or goods directly or indirectly received by employees as compensation for services provided to agencies. Ranupandojo (2012: 24) which states that compensation includes activities of providing remuneration to employees. Activities here include determining a compensation system that is able to boost employee performance, and also determining as amount of compensation that will be received by each employee. Meanwhile, according to Dessler (2013: 45) compensation refers to all forms of payment or gifts for employees and comes from their work. So it can be said that compensation is a form of reward received by employees in relation to rewards or remuneration for their work performance, both regularly and situational. From above understanding, it can be seen characteristics of reward or compensation, namely:

1. Compensation refers to all forms of financial benefits.

2. Compensation is obtained from tangible services and benefits received by employees as part of an employment relationship.

3. Compensation is a financial award given to employees.

\section{Purpose of Compensation}

The purpose of providing compensation (remuneration) are:

1. Cooperation ties between employees and employers will be established through provision of compensation. Employers are obliged to pay compensation to employees who have fulfilled / performed their duties properly.

2. Job Satisfaction will be felt by employees with compensation or remuneration so that employees can meet their physical needs, social status, and selfishness.

3. Effective procurement of qualified employees will be easier if compensation is large enough. 


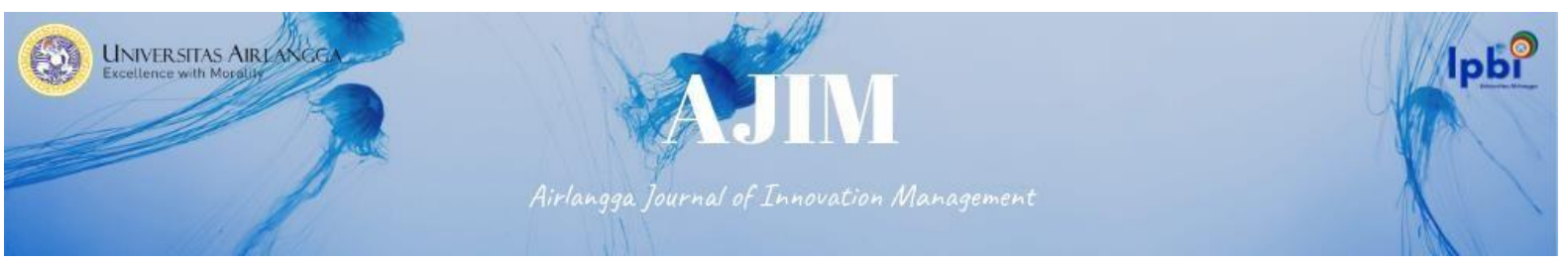

4. Employers will easily motivate employees, if compensation given is large enough.

5. Employee Stability is happened if compensation is given based on fair and proper principles, then employee stability will be guaranteed due to relatively small turnover.

6. Giving a large enough compensation is expected to build better employee discipline. Employees will obey and be aware of every regulation set in company.

7. Good compensation program, is hoped that employees can concentrate on their work and influence of labor unions can be avoided.

8. Government will not give influence to companies that have determined compensation in accordance with applicable labor laws such as minimum wages.

\section{Compensation Type}

Slamet (2011: 23) divides compensation into two groups, namely direct and indirect compensation:

1. Direct compensation includes:Basic salary, which is basic compensation received by an employee, is usually in form of wages or salaries. Meanwhile, salary is a direct financial reward that is paid to employees on a regular basis. Variable income is a type of compensation that is linked to individual, team, or organizational performance. Examples of variable income:a) Bonus is an extra payment on time at end of a period, where a job performance appraisal will be carried out;b) Commission is a compensation for achieving certain sales targets; c) Stock options is a form of compensation that allows employees to buy part of employee's agency shares at a special price; d)Incentives are direct rewards paid to employees because their performance exceeds predetermined standards; e) Profit sharing is part of the agency's profits to be paid to employees.

2. Indirect compensation, including: a) Employee benefits; Additional privileges other than compensation payments such as non-office payments (training, work leave, sickness, red day holidays, private events, rest periods, health insurance, and pension programs); b) Position Allowance; Additional privileges besides payment of compensation and employee benefits.

\section{Compensation Indicator}

Indicators in compensation include followings:

1. Wages are usually related to hourly wage rates. Wages are basis of payment which is often used for production and maintenance workers. And Salaries generally apply to weekly, monthly, or yearly rates.

2. Incentives are additional compensation above or beyond the salary or wages provided by the organization.

3. Allowances can be as a health and life insurance, company-borne vacations, pension plans, and other benefits related to employment relationships.

4. Facilities can represent a substantial amount of compensation, especially for executors who are well paid. Examples of facilities are enjoyments / amenities such as company cars, club memberships, designated parking spaces, or employee-acquired access to company aircraft.

Employees' needs for income and their wants are treated fairly by organization, making compensation programs even more vital to human resources department. Compensation is what employees receive in exchange for their contribution to organization. Compensation is often used interchangeably with administration of salaries and wages; however, term compensation is actually a broader concept. When managed properly, compensation helps organization achieve its goals and obtain, maintain a productive workforce. The components of overall compensation program can be divided in forms of direct compensation and indirect compensation. Direct financial compensation consists of pay that a person receives in form of salaries, wages, bonuses and commissions. Indirect 


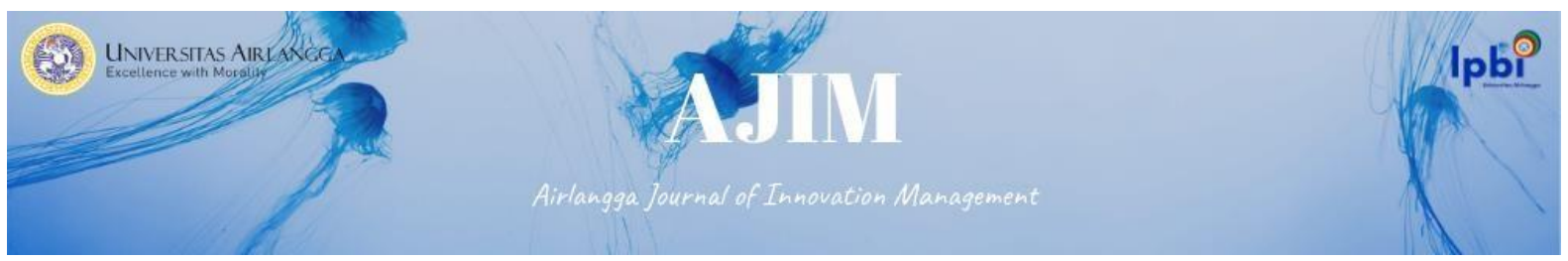

financial compensation, which is also called allowance, includes all financial benefits that are not covered by direct compensation.

Non-financial compensation consists of satisfaction a person gets from job itself, or psychological or physical environment in works. This type of non-financial compensation includes satisfaction obtained from performing meaningful tasks related to work. Compensation is a strategic human resource function that has a significant impact on other human resource functions. Financial compensation also affects the overall strategy of organization because compensation has a strong influence on job satisfaction, productivity, employee turnover and other processes in organization.

Organizations must attract, motivate and retain competent employees. If this can be achieved through a compensation system, then organization must strive to provide fair compensation. If employees feel that they are being compensated unfairly, they will limit or reduce their work productivity or may even leave company and look for other jobs. In other words, compensation inequality can lead to poor overall organizational performance. A design and implementation of compensation system must ensure that there is external justice, internal justice and individual justice through design and establishment of an effective salary structure and appropriate pay levels.

\section{Employee Performance}

According to Martoyo (2004: 88), performance is a process related to human resource activities in carry out assigned work, involving activities of elements used in a process to produces output, and becomes system and standards used by organization in achieving goal. Likewise, view of Husnan (2004: 114) that performance is teaching achievement or teaching results. The ability to carry out task or performance is something that can continuously improve a motivation function.

\section{Methods/Materials}

In this data analysis, researcher will analyze research data descriptively, both from primary and secondary data. This study uses a quantitative approach. As according to Sugiyono (2013) that quantitative research methods can be interpreted as research methods based on philosophy of positivism, used to research on certain populations or samples. The population in this study were 53 employees at the Food Security and Animal Husbandry Service Office of North Sumatra Province. In this data analysis, researcher will analyze research data descriptively, based on both primary and secondary data.

\section{Respondent Identity Based on Education Level}

Table 1. Identity of Respondents based on Education Level

\begin{tabular}{|l|l|l|l|}
\hline No & Education Level & Number & Presentage \\
\hline 1 & Senior High School / equivalent & 7 & 13,7 \\
\hline 2 & Diploma & 4 & 7,8 \\
\hline 3 & Bachelor & 25 & 49 \\
\hline 4 & Postgraduate & 15 & 29 \\
\hline & Total & & \multicolumn{2}{|c|}{$100,0}$. \\
& & & \\
\hline
\end{tabular}

Source : Food Security and Animal Husbandry Service Office of North Sumatra, 2020 


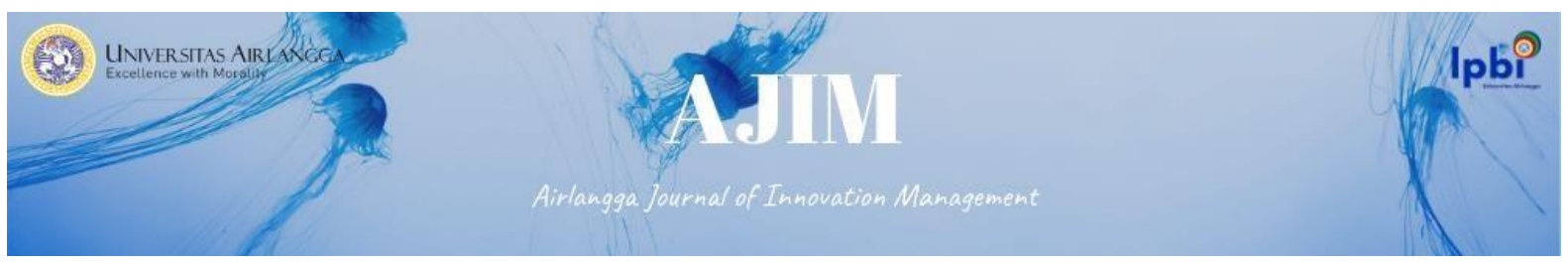

Respondent Identity based on Gender

Tabel 2. Identity of Respondents based on Gender

\begin{tabular}{|l|l|l|l|}
\hline No & Gender & Number & Presentage \\
\hline 1 & Male & 26 & 51,0 \\
\hline 2 & Female & 25 & 49,0 \\
\hline & & 51 & 100,0 \\
\hline
\end{tabular}

Source : Food Security and Animal Husbandry Service Office of North Sumatra, 2020

\section{Results and Discussion}

Score of Compensation Variable Questionnaire (X3)

From questionnaire given to 53 respondents, each respondent answered 10 questions. The results of questionnaire answers for compensation variable are tabulated, with detailed scores in Table 3 below.

Table 3. Score of Compensation Variable Questionnaire

\begin{tabular}{|c|c|c|c|c|c|c|c|c|c|c|c|c|}
\hline \multicolumn{13}{|l|}{$\mathbf{X 3}$} \\
\hline \multirow{3}{*}{ No. } & \multicolumn{12}{|c|}{ ALTERNATIVE ANSWER } \\
\hline & \multicolumn{2}{|l|}{$\mathbf{A}$} & \multicolumn{2}{|l|}{ B } & \multicolumn{2}{|l|}{$\mathbf{C}$} & \multicolumn{2}{|c|}{$\mathbf{D}$} & \multicolumn{2}{|c|}{$\mathbf{E}$} & \multicolumn{2}{|c|}{ Number } \\
\hline & f & $\%$ & f & $\%$ & f & $\mathbf{F}$ & f & $\%$ & f & $\%$ & f & $\%$ \\
\hline 1 & 3 & 5,9 & 31 & 60,8 & 17 & 33,3 & 0 & 0,0 & 0 & 0,0 & 51 & 100,0 \\
\hline 2 & 4 & 7,8 & 38 & 74,5 & 9 & 17,6 & 0 & 0,0 & 0 & 0,0 & 51 & 100,0 \\
\hline 3 & 2 & 3,9 & 36 & 70,6 & 13 & 25,5 & 0 & 0,0 & 0 & 0,0 & 51 & 100,0 \\
\hline 4 & 5 & 9,8 & 39 & 76,5 & 7 & 13,7 & 0 & 0,0 & 0 & 0,0 & 51 & 100,0 \\
\hline 5 & 3 & 5,9 & 34 & 66,7 & 14 & 27,5 & 0 & 0,0 & 0 & 0,0 & 51 & 100,0 \\
\hline 6 & 12 & 23,5 & 30 & 58,8 & 9 & 17,6 & 0 & 0,0 & 0 & 0,0 & 51 & 100,0 \\
\hline 7 & 4 & 7,8 & 19 & 37,3 & 28 & 54,9 & 0 & 0,0 & 0 & 0,0 & 51 & 100,0 \\
\hline 8 & 3 & 5,9 & 37 & 72,5 & 11 & 21,6 & 0 & 0,0 & 0 & 0,0 & 51 & 100,0 \\
\hline 9 & 6 & 11,8 & 22 & 43,1 & 23 & 45,1 & 0 & 0,0 & 0 & 0,0 & 51 & 100,0 \\
\hline 10 & 3 & 5,9 & 25 & 49,0 & 23 & 45,1 & 0 & 0,0 & 0 & 0,0 & 51 & 100,0 \\
\hline
\end{tabular}

Validity Test

Tabel 4. Result of Variable Validity Test $\left(\mathrm{X}_{3}\right)$

\begin{tabular}{|c|l|l|l|}
\hline Question number & r-score & r-table & Information \\
\hline 1 & 0,353 & 0,276 & Valid \\
\hline 2 & 0,547 & 0,276 & Valid \\
\hline 3 & 0,561 & 0,276 & Valid \\
\hline 4 & 0,274 & 0,276 & Not Valid \\
\hline 5 & 0,284 & 0,276 & Valid \\
\hline 6 & 0,337 & 0,276 & Valid \\
\hline 7 & 0,674 & 0,276 & Valid \\
\hline 8 & 0,409 & 0,276 & Valid \\
\hline 9 & 0,718 & 0,276 & Valid \\
\hline
\end{tabular}




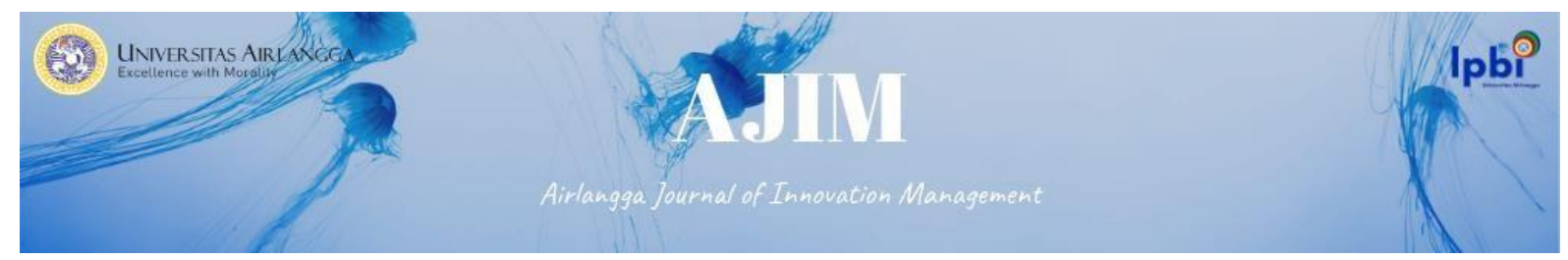

\begin{tabular}{|c|c|c|l|}
\hline Question number & r-score & r-table & Information \\
\hline 10 & 0,679 & 0,276 & Valid \\
\hline
\end{tabular}

Most of each variable has a corrected item correlation ( $r$-score) value greater than $r$-table and is declared valid. Corrected item correlation is one of parameters which aims to see suitability of item function with the function of whole scale. For invalid statements, it will not proceed to reliability test. Reliability Test

Tabel 5. Result of Variabel Reliability Test

\begin{tabular}{|c|c|c|l|}
\hline Variable & $\begin{array}{l}\text { Cronbach's } \\
\text { Alpha }\end{array}$ & N of Items & $\begin{array}{l}\text { Reliability } \\
\text { Status }\end{array}$ \\
\hline $\mathrm{X}_{1}$ & 0,889 & 10 & Reliable \\
\hline $\mathrm{X}_{2}$ & 0,815 & 10 & Reliable \\
\hline $\mathrm{X}_{3}$ & 0,659 & 9 & Reliable \\
\hline $\mathrm{Y}_{1}$ & 0,853 & 10 & Reliable \\
\hline
\end{tabular}

Based on table 6. above, it can be seen that Cronbach Alpha value of all variables ranges from 0 to 1 and is more likely to approach number 1 , thus all items in measurement instrument can be categorized as very reliable.

\section{Normality Test}

In SPSS output as in Figure 1. below, it is known that normal part of P-P Plot of Regression Standardized Residuals can be explained that data (dots) tend to follow a diagonal line so that data in this study tend to be normally distributed.

Graph 1. Data Normality

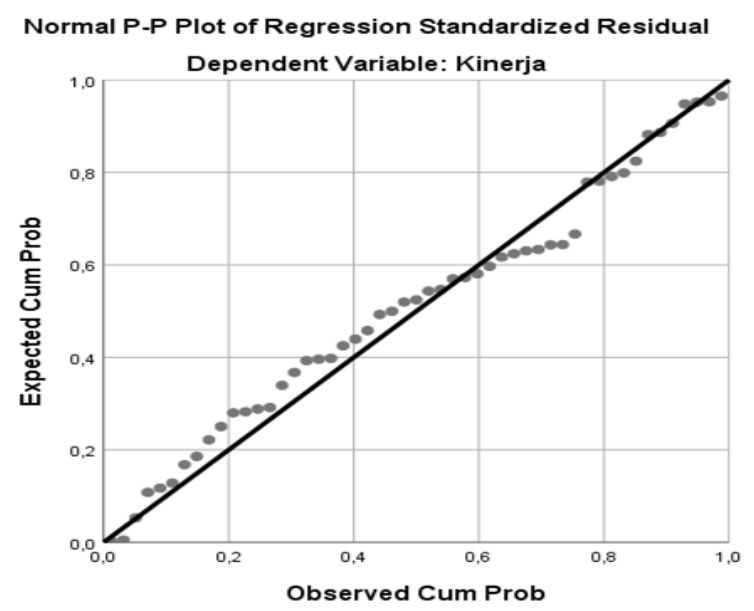

5) Multicollinearity Test

In the SPSS output section of the Coefficient table above, all VIF numbers are below 5, this indicates that there is no multicollinearity. 


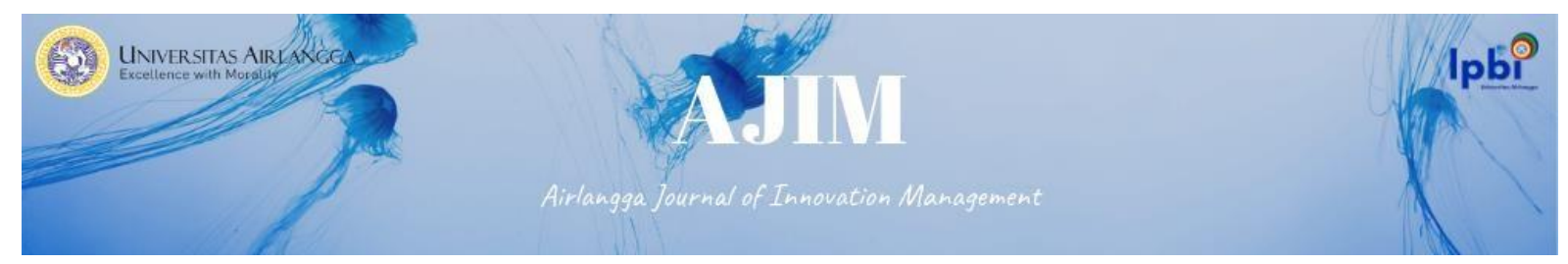

Tabel 6. Multicollinearity Test

\begin{tabular}{|c|c|c|c|c|c|c|c|c|}
\hline \multirow{3}{*}{ Model } & \multicolumn{8}{|c|}{ Coefficients $^{a}$} \\
\hline & & \multicolumn{2}{|c|}{$\begin{array}{l}\text { Unstandardized } \\
\text { Coefficients }\end{array}$} & \multirow{2}{*}{$\begin{array}{l}\text { Standardized } \\
\text { Coefficients } \\
\text { Beta }\end{array}$} & \multirow[t]{2}{*}{$\mathrm{T}$} & \multirow[t]{2}{*}{ Sig. } & \multicolumn{2}{|c|}{ Collinearity Statistics } \\
\hline & & $\mathrm{B}$ & Std. Error & & & & Tolerance & VIF \\
\hline \multirow{4}{*}{1} & (Constant) & 7,271 & 7,737 & & 940 &, 352 & & \\
\hline & Leadership style &,- 027 &, 152 &,- 029 &,- 179 &, 859 &, 562 & 1,778 \\
\hline & Motivation & ,460 &, 178 & ,428 & 2,584 &, 013 &, 538 & 1,857 \\
\hline & Compensation & ,386 &, 176 &, 277 & 2,194 &, 033 & ,930 & 1,075 \\
\hline
\end{tabular}

a. Dependent Variable: Working Performance

\section{Uji Heteroscedasticity}

Scatterplot pattern is shown in Figure 2. below, appears that dots spread randomly, do not form a clear pattern, and are spread either above or below the zero on Y axis. It means that there is no heteroscedasticity in regression model, so a regression model worth wearing.

\section{Figur2 1. Heteroscedasticity Test}

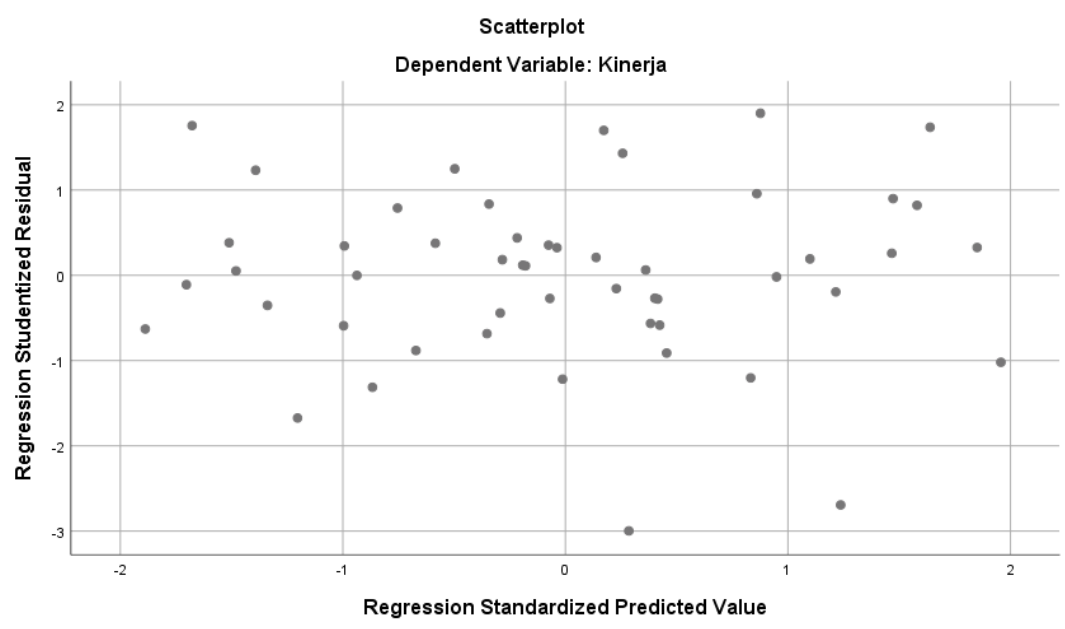

\section{Multiple Linier Regression Analysis}

$Y=7,271-0,027 X_{1}+0,460 X_{2}+0,386 X_{3}+\varepsilon$

Based on the above equation, coefficient of X3 (compensation) has a positive value of 0.386 . This shows that compensation variable has a positive influence on working performance of employees at Food Security and Animal Husbandry Office of North Sumatra Province. 


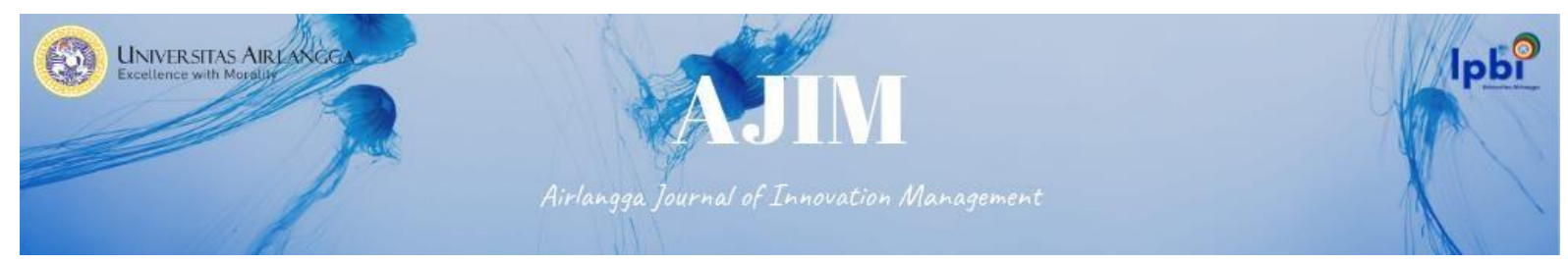

\section{Simultant Test (Uji F)}

Table 7. Anova Table

\begin{tabular}{|c|c|c|c|c|c|}
\hline ANOVA $^{a}$ & & & & & \\
\hline Model & Sum of Squares & df & Mean Square & $\mathrm{F}$ & Sig. \\
\hline Regression & 231,587 & 3 & 77,196 & 6,854 &, $001^{b}$ \\
\hline 1 Residual & 529,393 & 47 & 11,264 & & \\
\hline Total & 760,980 & 50 & & & \\
\hline
\end{tabular}

a. Dependent Variable: Working Performance

b. Predictors: (Constant), Compensation, Motivation, Leadership style

In Table 7. Above, it can be seen that F-score value is 6.854 and significance value is 0.001 . With degrees of freedom, namely df $1=\mathrm{k}-1=4-1=3$ and df $2=\mathrm{N}-\mathrm{k}=51-4=47$, then F-table value with a confidence level of $95 \%(\alpha: 0.05)$ is 2.80 .

Therefore, value of F-count> F-table $(6.854>2.80)$ and with a significance value of $0.001<0.05$, then $\mathrm{Ha}$ is accepted and Ho is rejected, which means that hypothesis in this study is that simultaneous compensation has a significant effect on employee performance at work. at Food Security and Animal Husbandry Office of North Sumatra Province.

\section{Partial Test (Uji T)}

Tabel 8. Results of Partial Compensation Test on Employee Performance

\begin{tabular}{|c|c|c|c|c|c|c|c|}
\hline \multirow{3}{*}{ Model } & \multicolumn{7}{|c|}{ Coefficients $^{\mathrm{a}}$} \\
\hline & \multicolumn{2}{|c|}{$\begin{array}{l}\text { Unstandardized } \\
\text { Coefficients }\end{array}$} & \multirow{2}{*}{$\begin{array}{c}\text { Standardized } \\
\text { Coefficients } \\
\text { Beta }\end{array}$} & \multirow{2}{*}{$\mathrm{t}$} & \multirow{2}{*}{ Sig. } & \multicolumn{2}{|c|}{ Collinearity Statistics } \\
\hline & $\mathrm{B}$ & Std. Error & & & & Tolerance & VIF \\
\hline Kompensasi & ,386 & ,176 & 277 & 2,194 & ,033 & ,930 & 1,075 \\
\hline
\end{tabular}

a. Dependent Variable: Kinerja

Partially an effect of compensation on employee performance at work can be seen in table 6 above. Based on table, the t-count value is 2.194 . While t-table value at $95 \%$ confidence level ( $\alpha: 0.05)$ is 2.012. Based on value of t-score>t-table (2.194> 2.012), it can be concluded that Ha is accepted and Ho is rejected, which means that partial compensation variable has a significant effect on employee performance in Food Security and Animal Husbandry Service of North Sumatra Province.

\section{Coefficient Determinant}

Tabel 9. Summary Model

\section{Summary Model}

\begin{tabular}{|c|c|c|c|c|}
\hline Model & $\mathrm{R}$ & R Square & Adjusted R Square & Std. Error of the Estimate \\
\hline 1 &, $552^{\mathrm{a}}$ & ,304 &, 460 & 3,35614 \\
\hline
\end{tabular}

a. Predictors: (Constant), Compensation 


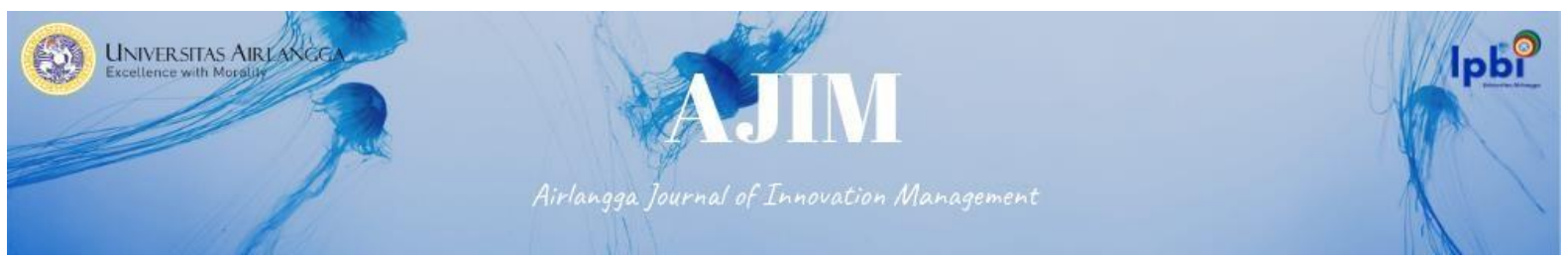

In Table 9. above, it shows that adjusted R2 value is $46.0 \%$, employee performance variable in working at Food Security and Animal Husbandry Office of North Sumatra Province can be explained by compensation variable while remaining $54.0 \%$ is not carried out in this study.

Partially effect of compensation on employee performance at work can be seen in table above. Based on table, t-score value is 2.194, while t-table value at the 95\% confidence level ( $\alpha: 0.05)$ is 2.012 . Based on t-score value \& gt; t-table (2.194 \& gt; 2,012), it can be concluded that Ha is accepted and Ho is rejected, which means that partial compensation variable has a significant effect on performance of employees in Food Security and Animal Husbandry Service of North Sumatra Province.

\section{Conclusion}

This study conclude that partial compensation variable has a significant effect on performance of employees at Food Security and Animal Husbandry Office of North Sumatra Province. In addition, value of Adjusted R Square is 0.460 or $46.0 \%$, which means that performance of employees at Food Security and Animal Husbandry Office of North Sumatra Province can be explained by compensation variable while remaining $54.0 \%$ is not carried out in this study. So that this study does not fully answer existing problems, because there are still 54, $0 \%$ who have not explained compensation variable. As for suggestions for further researchers, it will explain more in depth what variables really affect employee performance, so it does not only explain one variable about compensation.

\section{References}

Aritonang, Keke, T. 2005. Kompensasi Kerja, Disiplin Kerja Guru dan Kinerja Guru SMP Kristen BPK Penabur. (Jurnal Pendidikan Penabur). No. 4. Th. IV. Jakarta.

Dessler, 2007,Manajemen Personalia, Edisi Ketiga,Erlangga,Jakarta.

Husnan, Suad, 2004. Manajemen Personalia. Edisi Ke Empat, Yogyakarta : BPFE.

Handoko, T. Tani. 2003. Manajemen Personalia dan Sumber Daya Manusia. Edisi Kedua. Yogyakarta : BPPE.

Lateiner, A. R., \& Lavine, L. E. (1995). Teknik Memimpin Pegawai dan Pekerja (Terjemahan Imam Soedjono). Jakarta: Aksara Baru.

Leonard Adhi, 2017. Pengaruh Kompensasi Terhadap Kinerja Karyawan Toko Roti Muntjul Klaten Jawa Tengah (Studi Kasus Pada Karyawan yang Bekerja di Toko Roti Muntjul Klaten Jawa Tengah).

Mangkunegara. 2008, Manajemen Sumber Daya Manusia, Bandung: PT. Remaja Rosda Karya.

Martoyo, Susili 2004. Manajemen Sumber Daya Manusia. Edisi Ketiga, Cetakan Keempat, Ghalia Jakarta.

Moekijat, D. (1996). Pengembangan Manajemen dan Motivasi. Pionir Jaya Bandung.

Nitisemito, Alex S . Manajemen Personalia, Edisi Empat, Jakarta, Ghalia Indonesia,

Nurul Hidayah, 2016. Pengaruh Kompensasi Terhadap Kinerja Karyawan Melalui Kepuasan Kerja

Sebagai Variabel Intervening (Studi Kasus pada Karyawan Bagian Keuangan dan Akuntansi Universitas Negeri Yogyakarta).

Sedarmayanti, Manajemen Sumber Daya Manusia, Reformasi Birokrasi dan Manajemen Pegawai Negeri Sipil, Refika Aditama, Bandung, 2009.

Sugiyono, 2013, Metodelogi Penelitian Kuantitatif, Kualitatif Dan R\&D. (Bandung: ALFABETA). 


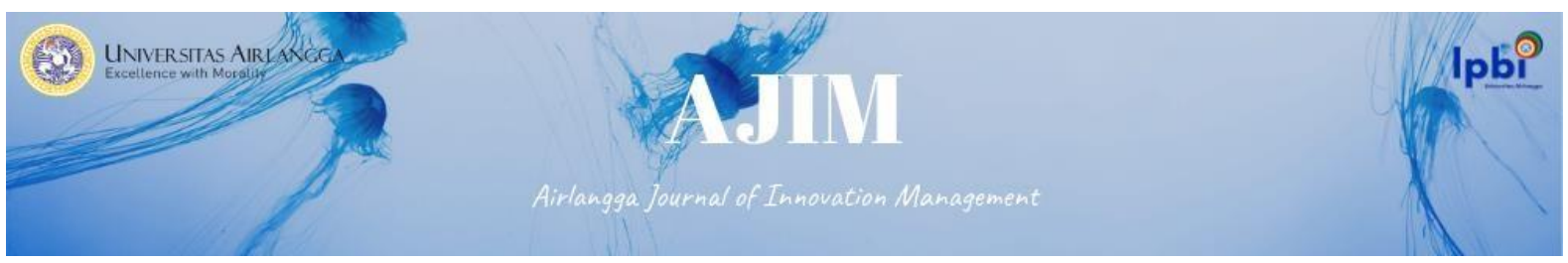

Sedarmayanti, Manajemen Sumber Daya Manusia, Reformasi Birokrasi dan Manajemen Pegawai Negeri Sipil, Refika Aditama, Bandung, 2009.

Saydam, G. (2000). Manajemen Sumber Daya Manusia (Human Resources Management): Suatu Pendekatan Mikro (Dalam Tanya Jawab). Jakarta: Djambatan.

Simamora, Henry, Manajemen Sumber Daya Manusia, STIE YKPN, Yo-gyakarta, 2003.

Slamet Riyadi, 2011. Pengaruh Kompensasi Finansial, Gaya Kepemimpinan dan Motivasi Kerja Terhadap Kinerja Karyawan Pada Perusahaan Manufaktur Di Jawa Timur.

Soeprihanto, J. (1996). Penelitian dan Pengembangan Karyawan. 